\title{
Finite Element Simulation of Acceleration Pedal On XX Vehicle
}

\author{
Nanang Ali Sutisna ${ }^{1, a}$, Aldhito Hardianto $2, b$ \\ ${ }^{1} J u r u s a n$ Teknik Mesin, Fakultas Teknik, Universitas Presiden, JABABEKA Education Park Jl. Ki Hajar \\ Dewantara, Cikarang Utara, Bekasi 17550 \\ ananang.ali@presiden.ac.id, baldhitohardianto@gmail.com
}

\begin{abstract}
Abstrak
Makalah ini membahas mengenai analisis kegagalan pedal gas pada sebuah kendaran xx. Tujuan dari penelitian ini adalah untuk mengetahui penyebab kegagalan, jenis kegagalan, dan pendekatan dalam mencari parameter terbaik yang menghasilkan kualitas produk yang optimal pada desain produk. Penelitian ini menggunakan metode uji yang telah dikenal, dimana jenis kegagalan dan hasil analisis dibandingkan dengan hasil keandalan produk yang diharapkan. Simulasi menggunakan perangkat lunak CATIA V5 yang melibatkan jenis beban yang diterapkan pada produk, panjang, ukuran dan dimensi produk, dan jenis material. Data hasil simulasi digunakan untuk melihat pengaruh dan pengaruh setiap parameter terhadap desain produk, juga jenis kegagalan yang akan mempengaruhi keandalan produk..
\end{abstract}

Kata kunci: Analisis Elemen Hingga, Simulasi, Kegagalan

\begin{abstract}
This paper presents the failure analysis of acceleration pedal of $\mathrm{xx}$ vehicle. The purpose of this research are to know the cause of failure, types of failure, and approach in searching for the best parameters that yield optimal product quality on product design. This research uses the known test method, where the type of failure and results of analysis compared with the result of expected product reliability. The simulation uses CATIA V5 software involving types of load that applied on product, length, size and dimension of product, and types of material. Simulation result data is used for see the influence and effect of each parameter to the product design, also the types of failure that will affect the product reliability
\end{abstract}

Keywords: Finite Element Analysis, Simulation, Failure

\section{Introduction}

A big problem in Product Development Process is to avoid failure of a machine or structure by predicting and analyzing potential failure scenarios at the design stage, before the machine is built. Either by identifying the loads, simulating the failure condition and selecting the appropriate material, these scenarios provide a basis for choosing the best combination of design parameters: geometry, material and loads. Usually, if load and material types were known, the failure of machine parts could be determined by simply operating loads or stresses never exceed the strengths at the most critical zones of the part. The topics will introduce the people to product related issues such as safety and reliability. It does also provide a better understanding of the design from a failure prevention perspective.

The case study for this thesis was taken from PT. XYZ. During the re-assembly process, the pedal broke. Which pique interest in finding the cause of the failure.

As the technology develops so was the effectiveness in analyzing the reliability and types of failure of the design. Many of the industrial company have increased the quality and reliability of the 
manufactured product. This research uses the known test method, where the calculation result compared with the result of expected product reliability that is simulated trough a software.

\section{Method}

\section{Existing Design Re-evaluation}

In order to study the failure of the acceleration pedal, it is important to do re-evaluation to the existing product. It is the evaluation of product design parameters for its ability in usage. To determine the effect or factors on the design itself that can affect results. This is done for determining the effect of design optimization.

The Design Evaluation experiments are one of the common methods in engineering that aimed at improving product and quality at the same time. This is used to provide a full layout of the existing design and to know the optimal operations of the intended design, and know the effect of the static and dynamic load parameters on existing surface.

The most possible cause of the crack that happened to the acceleration pedal is by fatigue. However, for the purpose of this study let us consider it is in static condition where the force from driver foot $\mathrm{F}$ is assumed $80 \mathrm{~kg}$. Even though the reaction force at point $\mathrm{A}$ can be calculated based on the equilibrium principle, it will be assumed that point $\mathrm{A}$ is fixed so that we can calculate the breakage stress at point $\mathrm{B}$.

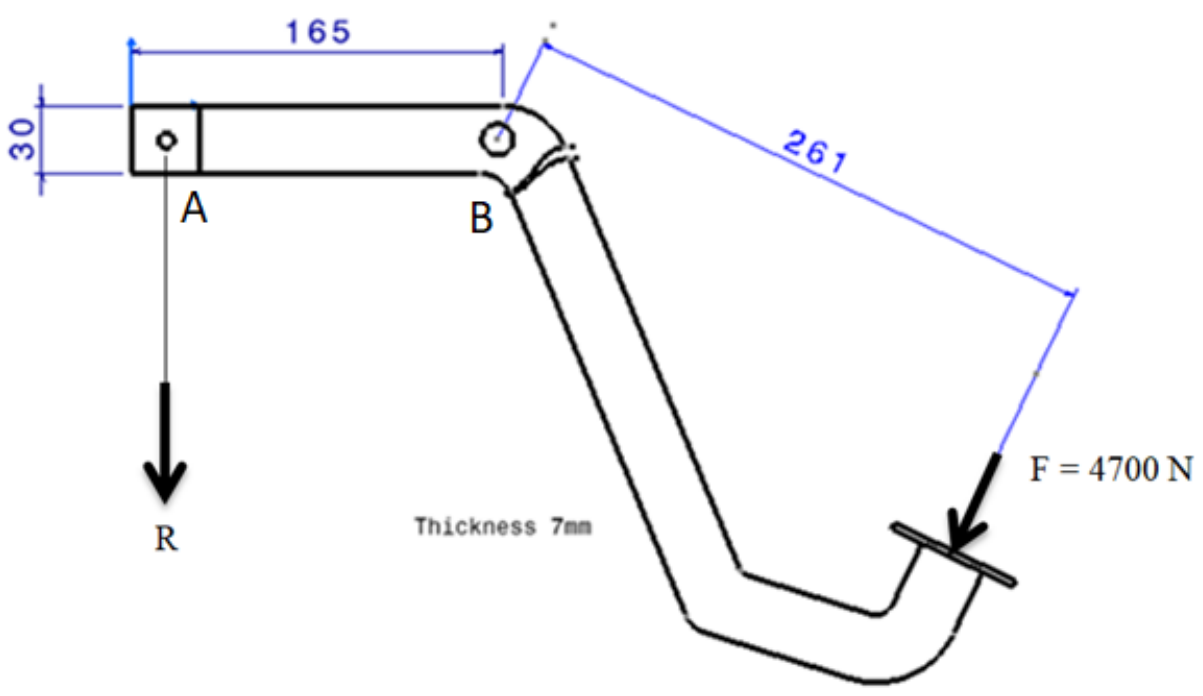

Figure 1. Original Model and Crack Location

Figure 1 above is the original model of the acceleration pedal, having width of $30 \mathrm{~mm}$ and thickness of $7 \mathrm{~mm}$. The Factor of Safety for vehicle component requires 6 at least and the maximum load to be applied to the pedal is $80 \mathrm{~kg}$ so that the maximum load is:

$$
\text { Max load F }=80 \times 9.81 \times 6=4700 \mathrm{~N}
$$

\section{Finite Element Method}


Finite element method is a numerical method for solving mathematical physics [2]. The scopes of the problems are fluid flow, structural analysis and many more. Finite Element Method has the ability to solve static and dynamics problem. In this case, it is suitable for the researcher's analysis regarding electric vehicle chassis. In the static case, it is possible to count manually even though it will require a lot time. But the main reason why we need to follow the calculation method of finite element is for the dynamic analysis. Through finite element method we can get some advantages:

- Less calculation time.

Counting manually will consume a lot of time not to mention for the dynamic analysis. It will requires more effort, more time, and the researcher wanted to use FEM in this research so it will results in a productive analysis.

- Less cost.

It does not require the researcher to build the model in real life to see what happens towards the model under study if it is applied by a given load. That is why it is effective to reduce cost.

\section{Governing Equations in Software}

\section{Von Mises Equations}

The Von Mises pressure is a standard for yielding, generally utilized for metals and other bendable materials. It expresses that yielding will happen in a body if the parts of pressure following up on it.

There are two ways of visualizing Von Mises stress in CATIA. The Von Mises Stress (Nodal Values) displayed using the Von Mises Stress icon and the Stress Von Mises (Nodal Values) displayed from the Stress Principal Tensor Symbol images can locally produce different results due to the two computation modes:

In the first case (Icon), the solver computation gives directly the result and the post processing performs a smoothing (Element to Node)

In the second case (Edit), The solver calculates the principal stress tensor, then the post processing performs a smoothing (Element to Node), diagonalizes the matrix, and calculates values using the formula:

$$
\sqrt{\left(\sigma_{1}-\sigma_{2}\right)^{2}+\left(\sigma_{2}-\sigma_{3}\right)^{2}+\left(\sigma_{3}-\sigma_{1}\right)^{2}}
$$

Where $\__{-} 1, \sigma \_2$ and $\sigma \_3$ are the principal stresses. The first method requires less time and performance.

\section{Error Rate}

There are two steps in the error computation: Stress smoothing and Error estimation.

The first method consists of computing a weighted nodal stress value at each node. Node stresses are extrapolations of element stresses.

The method consists in defining a continuous stress field within the element:

$$
\sigma \mathrm{x}=<\mathrm{N}>\sigma \mathrm{n}
$$


where:

$<\mathrm{N}>\quad$ are the element shape functions

on are the smoothed nodal stresses

These nodal stresses values are obtained using the least square minimization method:

$$
\text { Min } \sigma \mathrm{n}=\left[\int_{\mathrm{n}}(\sigma *-\sigma)^{T}(\sigma *-\sigma) d \Omega\right]
$$

Where $\sigma$ are the stresses computed with the finite element method from the nodal displacements.

In Error estimation method, once the nodal stresses values have been found, a continuous stress field is defined for each element:

$\sigma \mathrm{x}=<\mathrm{N}>\sigma \mathrm{n}$

where:

$<\mathrm{N}\rangle \quad$ are the element shape functions

on are the smoothed nodal stresses

The error for each element (local error) is:

$$
\mathrm{ei}=\int_{n}(\sigma *-\sigma) D^{-1}(\sigma *-\sigma) d \Omega i
$$

where:

$\sigma \quad$ is the finite element solution field

D is the Comportment Law

Element stresses at Gauss points are the product of the Comportment Law and the Strain Deformation.

$\sigma=\mathrm{D} \cdot \varepsilon$

Where:

$\sigma$ is the element stress

$\mathrm{D}$ is the Comportment Law, computed as a function of the following parameters, where:

$v$ is the Poisson Ratio

E is the Young's Modulus

$\varepsilon$ is the Strain deformation, computed according to the displacement.

For example, with a 2D displacement:

$$
\varepsilon=\frac{1}{2}\left(\frac{u}{x}+\frac{v}{y}\right)
$$

Where $\frac{u}{x}$ and $\frac{\mathrm{v}}{\mathrm{y}}$ are the two partial derivatives.

The total error (Estimated Precision) is the sum of all the local errors:

$$
\mathrm{e}=\sum_{i} \text { eie }
$$

And the Global Estimated Error Rate is: 


$$
\eta=100 \frac{\sqrt{\mathrm{e} / 2}}{\mathrm{E}+\mathrm{e} / 2}
$$

Where $\mathrm{E}$ is the global strain energy

\section{Finite Element Analysis Methodology}

The recommended methodology to use computed data is:

1. Set the preprocessing specifications:

- restraints

- loads,

- material

2. Launch the computation solver

3. Post processing (Von misses, Principal stress, Error rate).

4. Generate a report on computed data

In FEA, restrains refer to applying displacement boundary condition which is achieved through the Restraint toolbar. The Clamp conditions mean that the displacements in all three directions are zero.

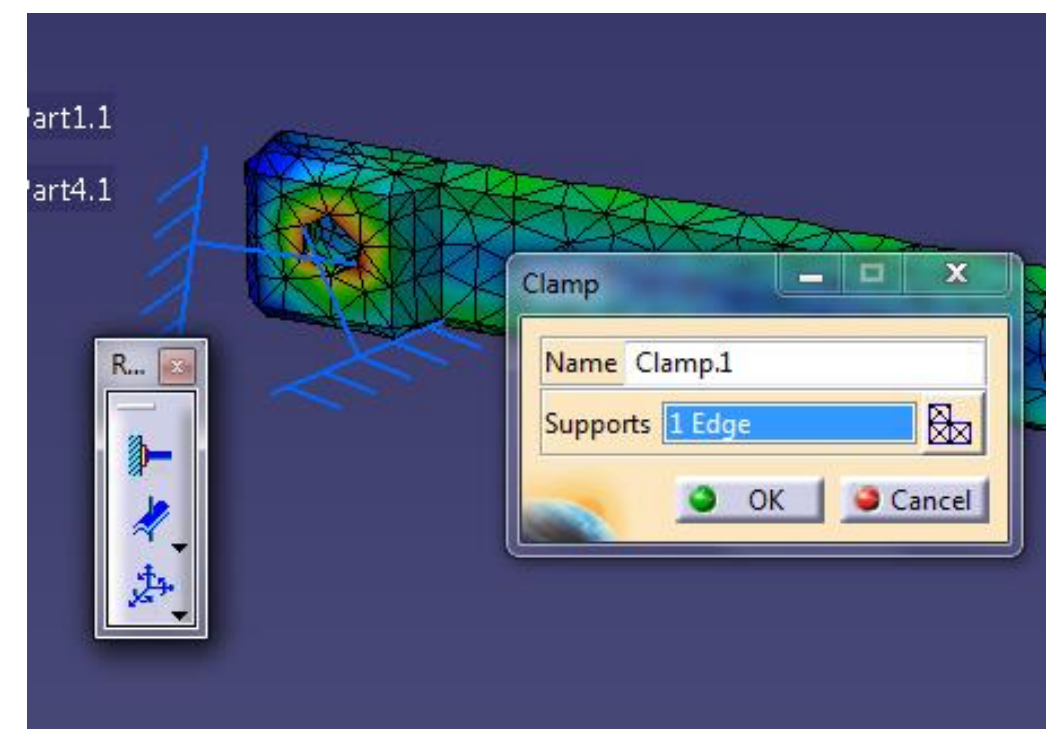

Figure2. Applying Restrains On Design

In FEA, loads refer to forces. The Loads toolbar is used for this purpose. Select The Distributed Force icon, and with the cursor pick the face that need to be loaded. In this case, because the front face is in total contact with force. 


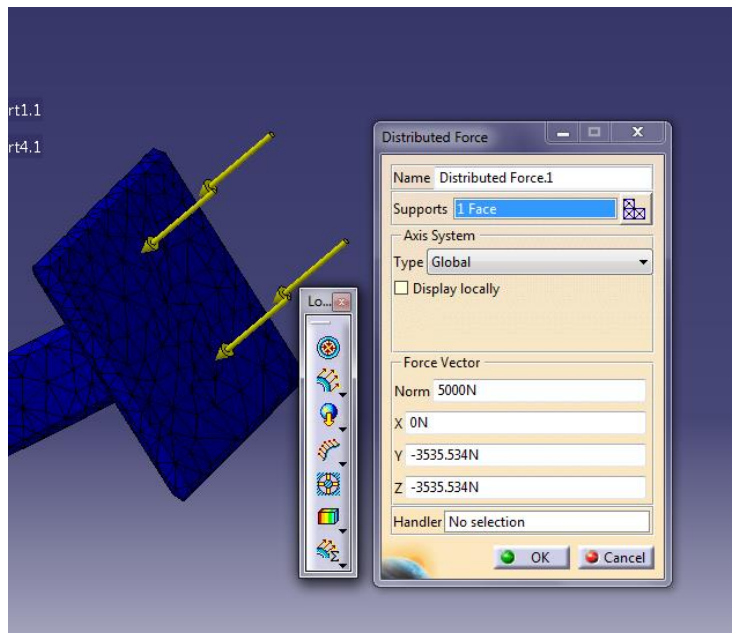

Figure 3. Applying Distributed Load on Specific Area

\section{Apply a material.}

The material used in AMMDES acceleration pedal is SS400 (Structural Steel) that has tensile strength of 400-510 MPa, yield strength of 205-245 MPa, and Young's modulus of 190-210 GPa. It is very important to apply a material because without this the simulation won't be running. A very important thing is to find the properties of a material. To find the material proprieties in CATIA is by double click on your material selected on the Tree and go to Analysis Tab. Here you can see the basic choice of the material you want to simulate for the model. You can also check the Structural Steel Properties by clicking the properties.

The type of steel properties in the CATIA as shown in the figure 4 is according to the acceleration pedal steel properties of XX vehicle. So there's no calibration n needed upon the structural properties required. All that's left is to close the steel properties page and click ok to apply the desired material into the design

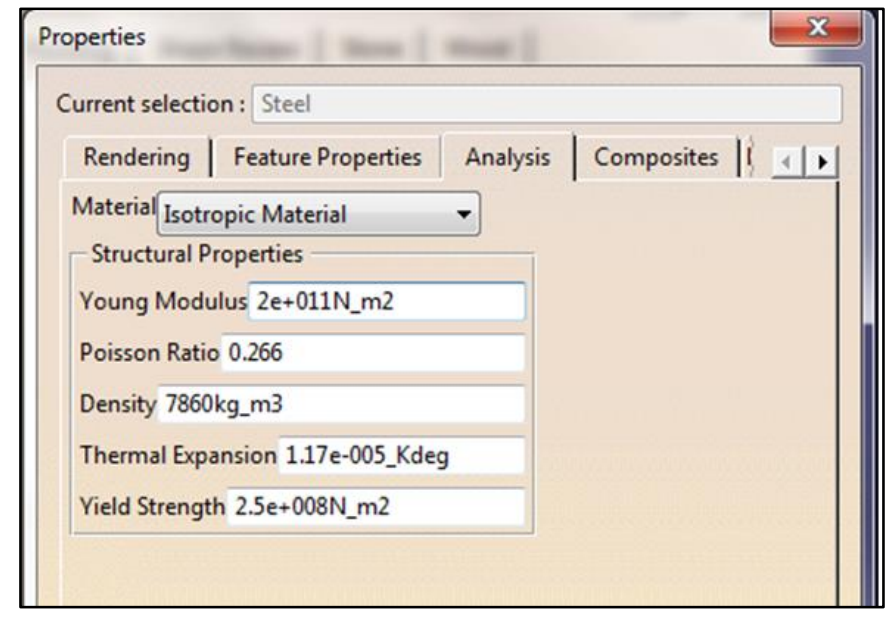

Figure 4. SS400 Properties of Material

\section{Mesh Size Refinement}

As indicated earlier, a smaller mesh could result in a more accurate solution, but this is not indiscriminately. The elements must be small in the regions of high stress gradient such as stress concentrations. Geometry changes rapidly such as bends, fillets, and keyways. Uniformly reducing the element size for the whole part is a poor strategy. 
Mesh size refinement is established by reducing the mesh size until the result is stable and the targeted precision is achieved. Generally mesh resizing is achieved either by manually reducing the mesh size or by using adaptive method.

\section{a. Reducing the Element Size Manually}

Reducing the element size is the easiest mesh refinement strategy, with element sizes reduced throughout the modeling domains. This approach is attractive due to its simplicity, but the drawback is that there is no preferential mesh refinement in regions where a locally finer mesh may be needed.

The following sample in figure 5 shows manual mesh refinement with uniform size. The smaller the size the more accurate the solution, however the calculation time is longer.

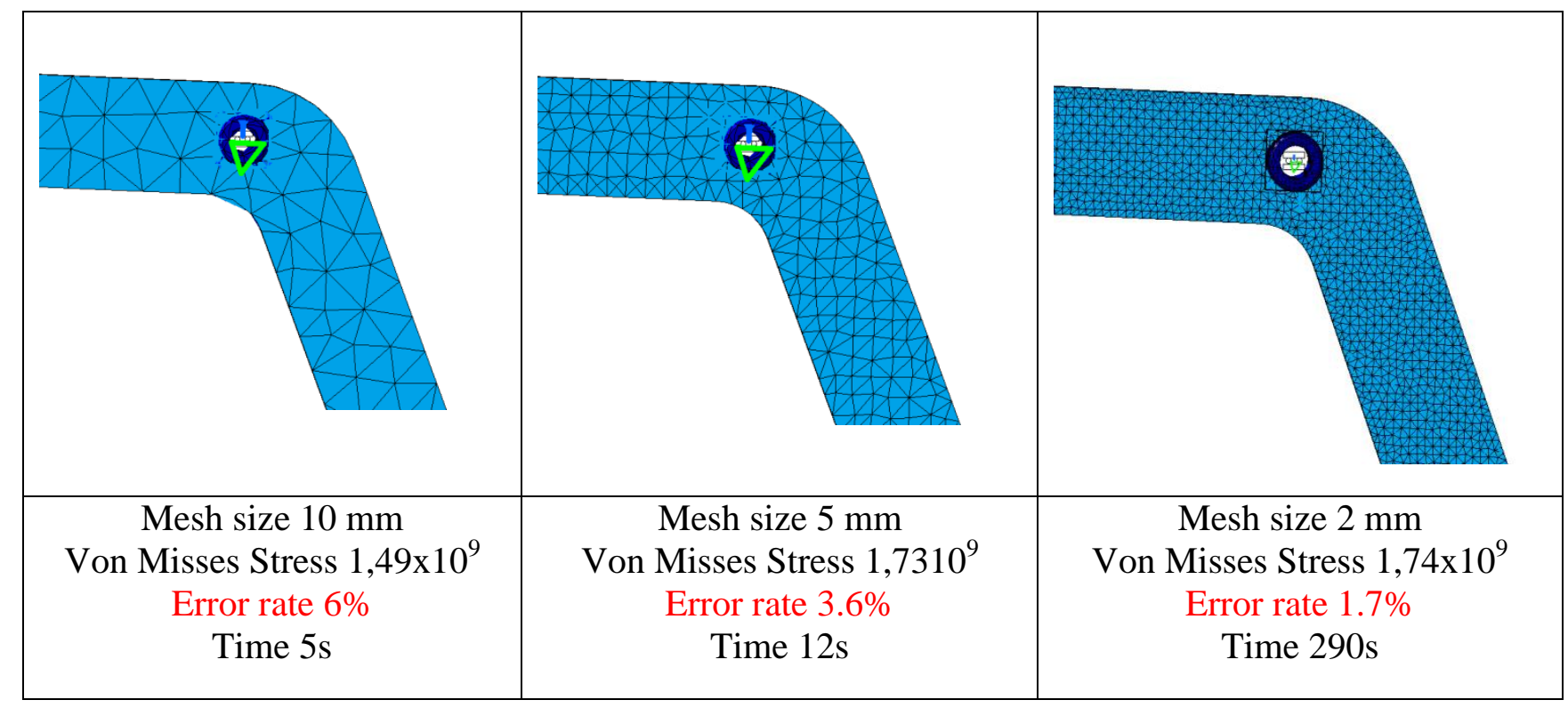

Figure 5. Example of Manually Mesh Refinement

\section{a. Global Adaptive Mesh Refinement}

Global Adaptive Mesh Refinement utilizes a blunder estimation procedure to decide the point in the displaying area where the local error is biggest. Smaller components are utilized in areas where the nearby blunder is critical, and the local error all through the model is considered. The preferred standpoint here is that the product will do the majority of the work refinement. The disadvantage is that the client has no influence over the work. All things considered, over the top work refinement may happen in areas that are of less intrigue, regions where a bigger local error is acceptable. Global adaptive mesh refinement strategy provide ease of operation as it is automatically refine the necessary mesh to the size that provide the targeted accuracy while keeping the size of less significant elements, as it is shown in figure 6 . 


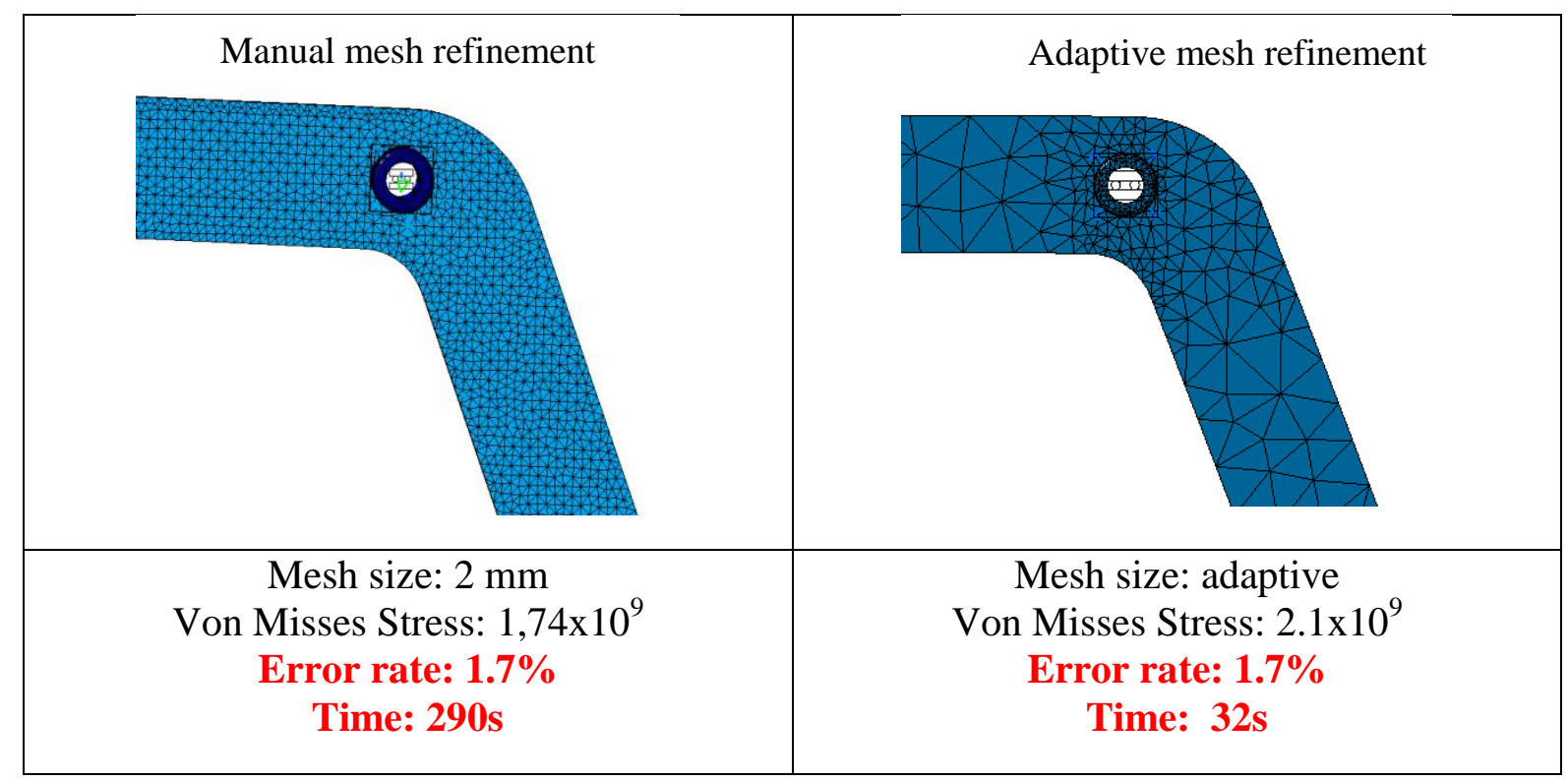

Figure 6. Example of Global Adaptive Mesh Refinement

\section{Launching the Solver (Compute)}

To run the analysis, we use the Compute toolbar by selecting the Compute icon. In the Compute box leave the defaults as All which means everything is computed. Usually if the estimates are zero in the listing, then there is a problem in the previous step and should be looked into.

\section{Postprocessing}

The main post processing toolbar is called Image. To view the deformed shape we have to use the Deformation icon. The deformation image can be very deceiving because we have the impressions that the bending is severe. Displacements are scaled considerably so observe the deformed shape. Displacement value is available on Image toolbar. The default display is in terms of displacement arrows as shown on the right. The color and the length of arrows represent the size of the displacement. 


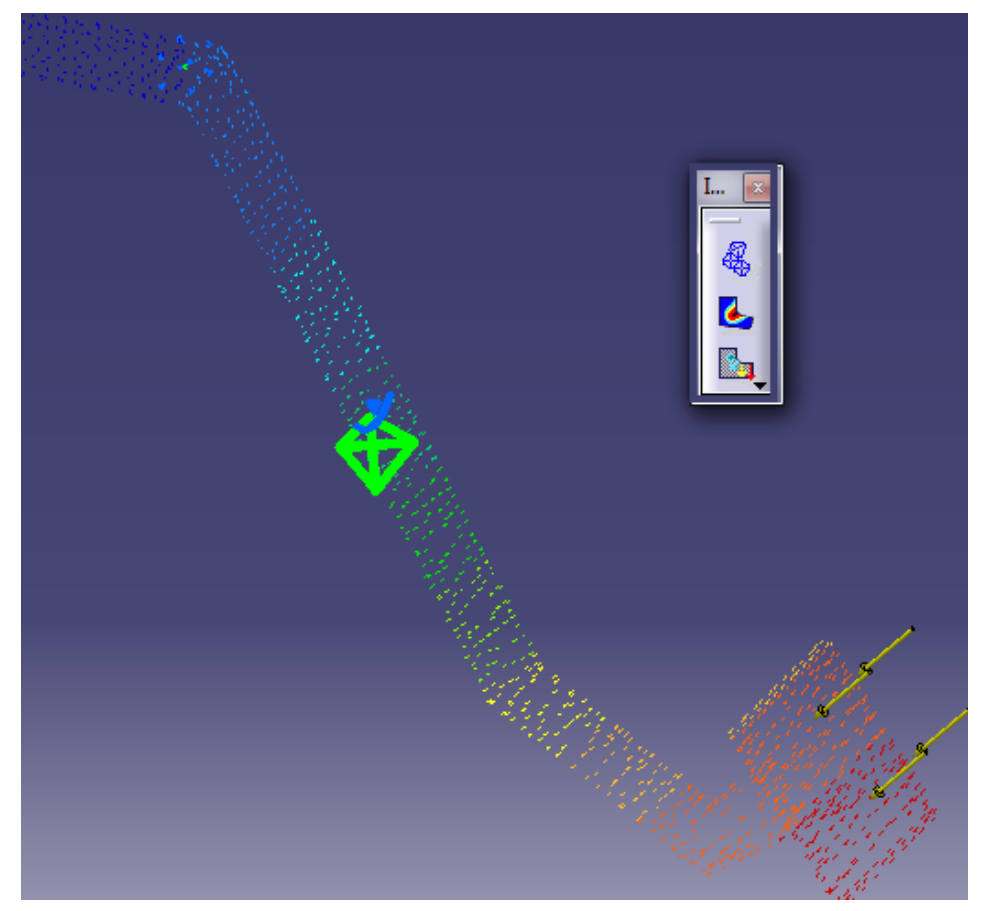

Figure 7. Displacement Image

Von Mises Stress is also available on Image toolbar. The von Misses stress is displayed to the right as shown in figure 8 . The maximum stress is $1.73 \mathrm{GPa}$ which is larger than the tensile strength of most steels. Principal Stress image shows the stress tensor in three dimensional direction on every nodes, and finally the Global Estimated Error image gives you the insight about the level of precision of the simulation being done.

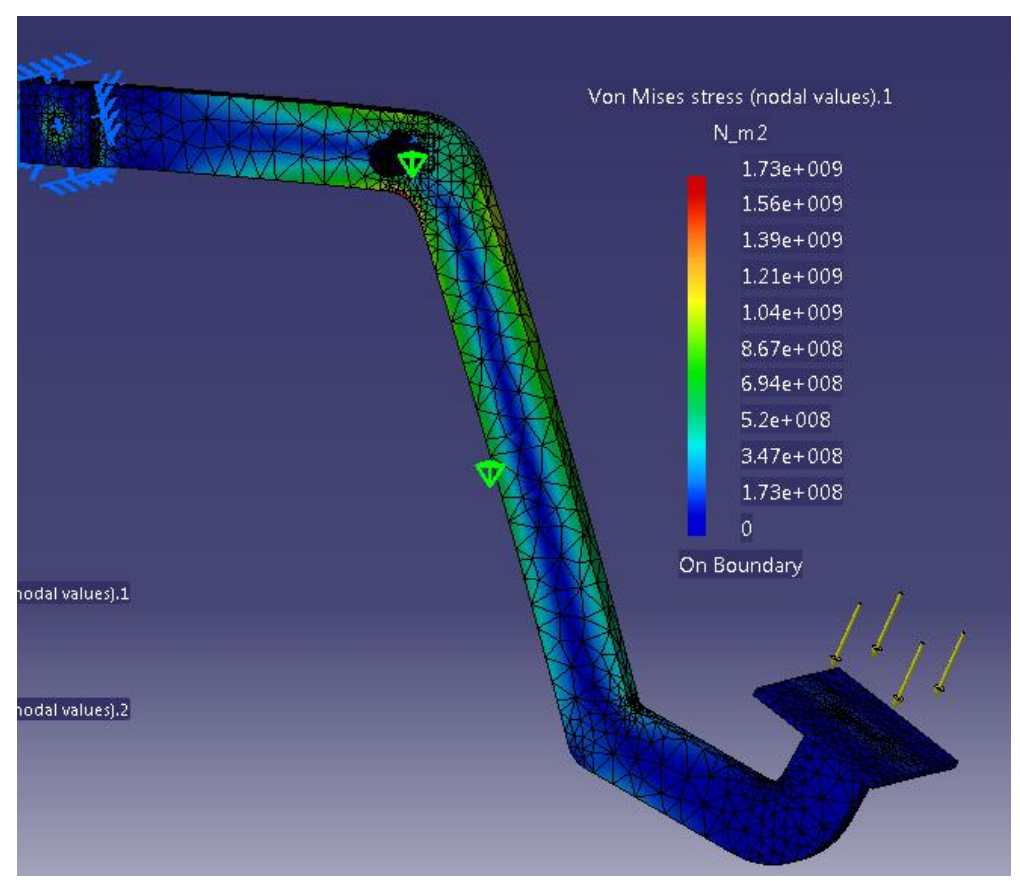

Figure 8. Von Mises Image 


\section{Model Improvement}

The improved model is mostly focused on adding more the thickness and width width of the previous design parameter, the new model has $15 \mathrm{~mm}$ thickness and $50 \mathrm{~mm}$. This is due to the problems is mainly focused on the same type of material, which is steel SS 400 and the same as original model. The factor that also affects the improved model to reach the expected reliability is the types of corner it has, evaluation of support shaft, and the distributed forces that acting on the design.

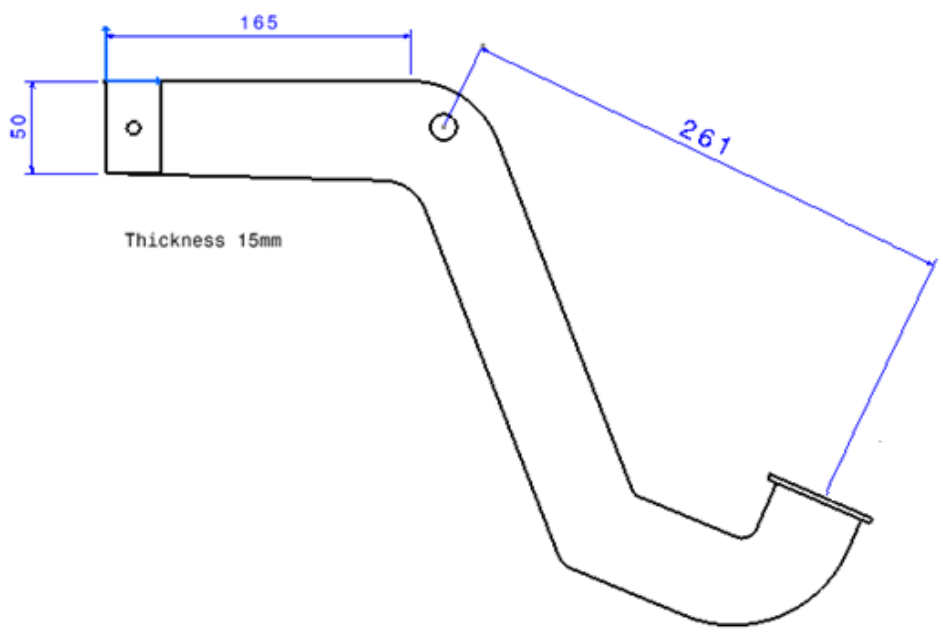

Figure 9. Improved Model

From figure 10 below, the Von Mises stress result is showing a very good result of the new acceleation pedal model after it's been calibrated. It yields very low error rate in computation calculations, and the Von Mises stress only show a load stress of $310 \mathrm{MPa}$ which is still below the maximum Tensile Strength.

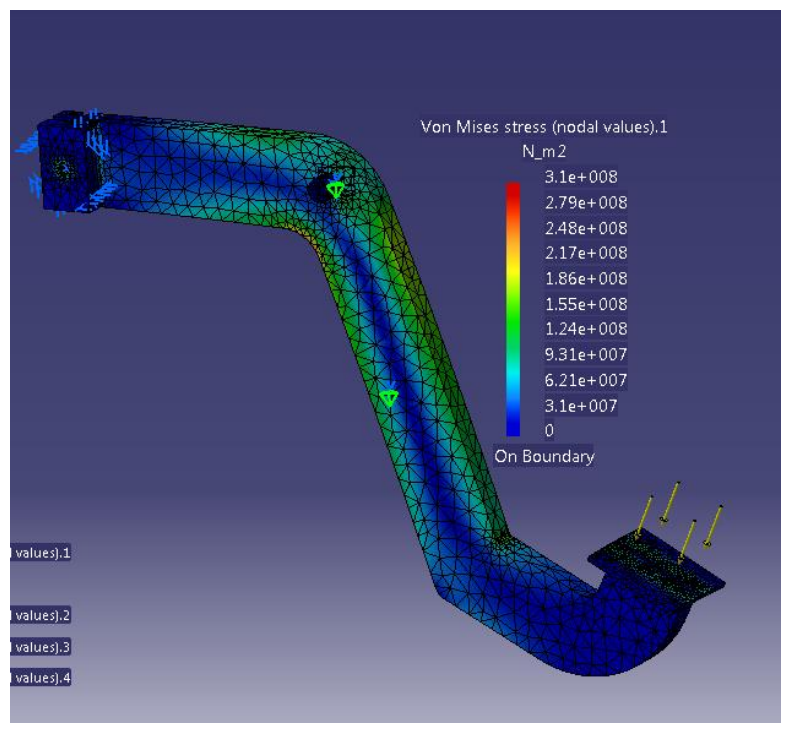

Figure 10. Von Mises stress of Improved Model 


\section{Von Mises Stress Result}

From figure 11 below, we can see that the improved model has been successful, with the estimated result with software computation, the Von Mises Stress for the basic model is $1.6 \mathrm{GPa}$ which is higher than the Tensile Strength of the acceleration pedal material, i.e. $400 \mathrm{Mpa}$. Compared to the Improved Model, with only around $80 \mathrm{MPa}$. This is still lower than the Tensile Strength of steel SS-400 that used on the acceleration pedal design. Thus, the reliability in Factor of Safety (FS) of 4 is achieved as it intended to.

The only difference by changing the Mesh size manually and using the Global Adaptivity is that the spreadsheet of the Mesh size within the acceleration pedal model surface area. If we use the manual route, the whole surface of the acceleration pedal Mesh would be the same size (Example, 10mm).

But if we use the Global Adaptivity, the Mesh size only smaller in the critical area. Resulting a way faster calculation time required. For the cases above, both of the model is using Global Adaptivity. But the improved model has smaller Mesh than the basic model resulting in much longer calculation.

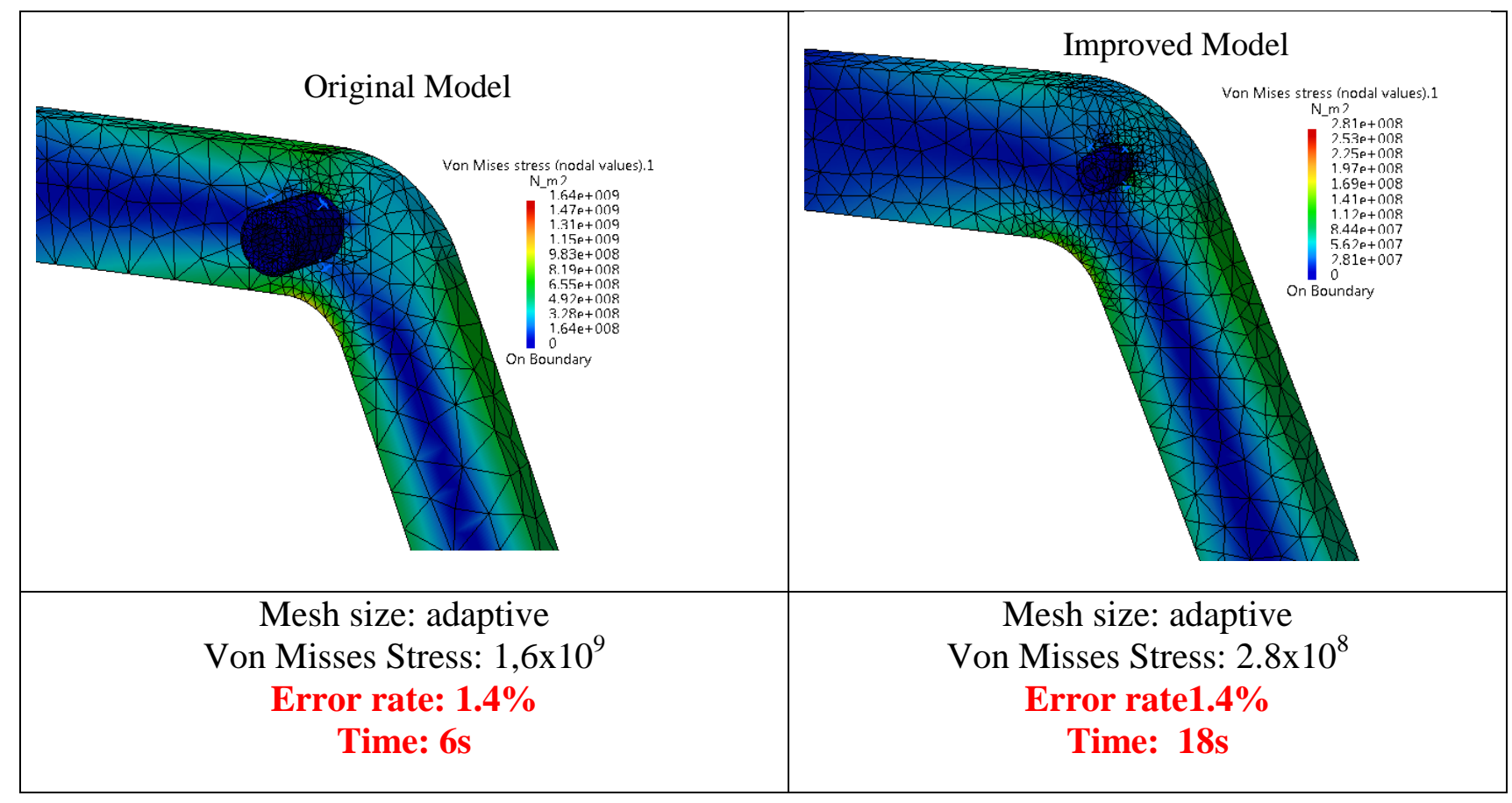

Figure 11. Von Mises stress of Original model and Improved Model

\section{Principal Stress Result}

Using the Principal Stress view we can see the amount of stress that acted upon the failure location of the acceleration pedal. It's showed that in the case of original model, the amount of stress that accumulated on that location around $700 \mathrm{Mpa}$ and $780 \mathrm{Mpa}$ on manual calculation, way over the Tensile Strength of the acceleration pedal.

However, for the improved model, the stress that acted upon the failure location is just around 120 Mpa whereas in manual calculation is $130 \mathrm{MPa}$. Lower than the Yield Strength of the acceleration pedal material. Thus, upon the intended stress the acceleration pedal will still be in the safety area. 


\section{Journal of Mechanical Engineering and Mechatronics 2019}

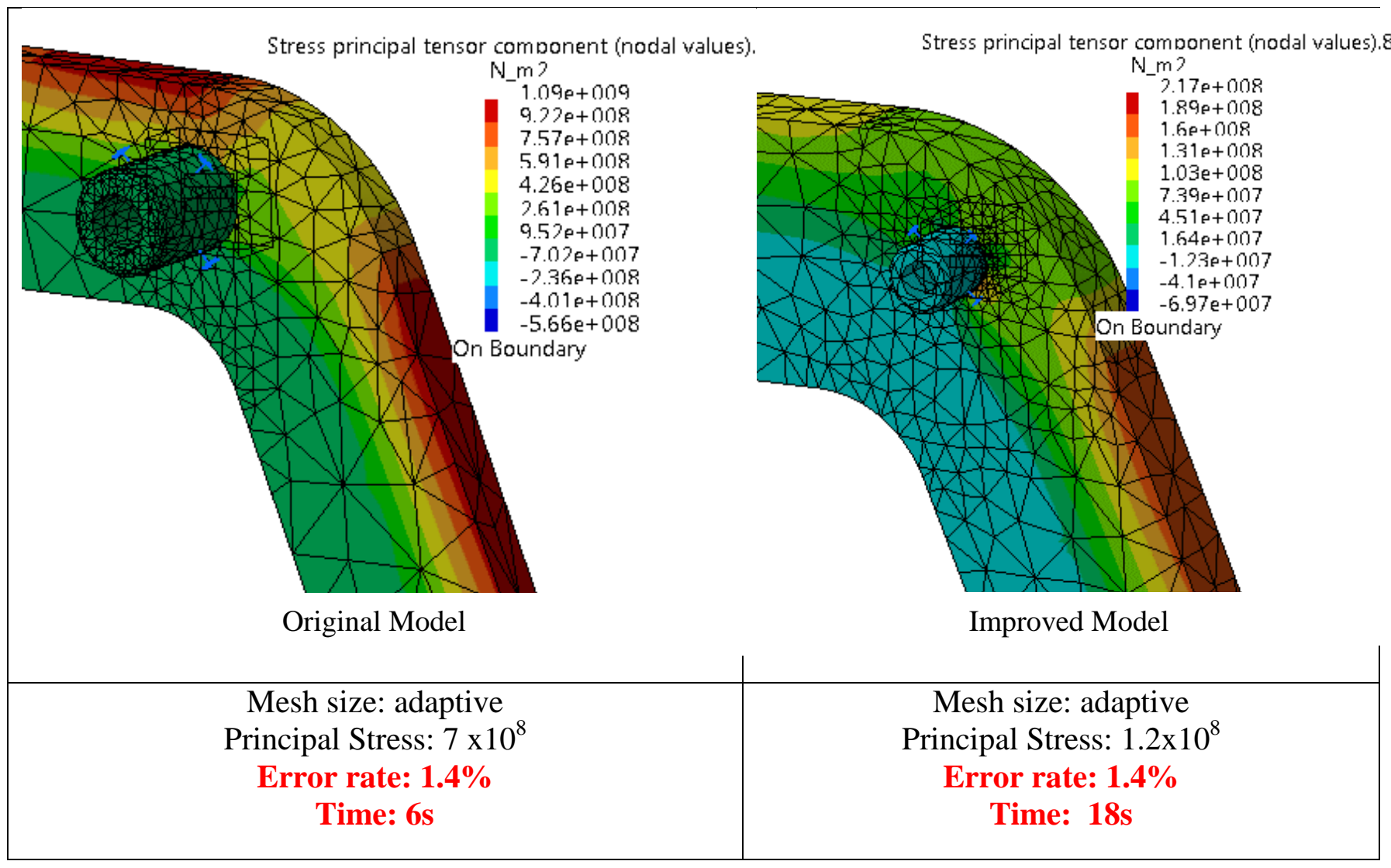

Figure 12. Principal stress of Original model and Improved Model

Based form the Generative Structural Analysis above, we can see Von Mises and Principal stress of both original model and improved model with the same precision. Manual calculation results is also included.

Table 4.2 Von Mises and Principal Stress Results

\begin{tabular}{|l|c|c|c|c|}
\hline \multicolumn{1}{|c|}{ Model } & $\begin{array}{c}\text { Von Mises } \\
\text { Stress }\end{array}$ & $\begin{array}{c}\text { Principal Stress } \\
\text { maximum }\end{array}$ & $\begin{array}{c}\text { Principal Stress } \\
\text { (Manual) }\end{array}$ & $\begin{array}{c}\text { Global Estimated } \\
\text { Error }\end{array}$ \\
\hline Original Model & $1.6 \mathrm{GPa}$ & $\mathbf{7 0 0} \mathrm{MPa}$ & $\mathbf{7 8 0} \mathrm{MPa}$ & $1.4 \%$ \\
\hline Improved Model & $\mathbf{2 8 0} \mathrm{Mpa}$ & $120 \mathrm{MPa}$ & $130 \mathrm{MPa}$ & $1.4 \%$ \\
\hline
\end{tabular}

From the table above we can see that the improved model has been successful, with the estimated error rate $1.4 \%$ which is a pretty accurate result with less error in software computation. The Von Mises stress also $280 \mathrm{MPa}$ which is much lower compared to the original model that has Von Mises stress value of $1.6 \mathrm{GPa}$. This is also still lower than the Tensile Strength of steel that used on the acceleration pedal design, $400 \mathrm{MPa}$. Thus, the reliability in Factor of Safety of 4 is achieved as it intended to be.

\section{Fatigue Life Expectancy}




\section{Journal of Mechanical Engineering and Mechatronics 2019}

\section{Original Model S-N Diagram}

Since the material used for the acceleration pedal is SS400, it has the Tensile Strength of 400 Mpa, and therefore

$$
S_{u}=400 \mathrm{Mpa}
$$

The endurance limit or $S_{e}$ of most steels is $0.5 S_{u}$, which means the endurance limit of the SS400 steel is

$$
S_{e,}=200 M p a
$$

The acceleration pedal shaft has a principal stress of $700 \mathrm{Mpa}$ at maximum stress and principal stress of $300 \mathrm{Mpa}$ at the minimum stress. The amount of force exerted on the surface area of the acceleration pedal would be:

$$
\begin{aligned}
& S_{m}=700 \mathrm{Mpa} \\
& S_{a}=300 \mathrm{Mpa}
\end{aligned}
$$

Now, to determine the stress components:

$$
\begin{aligned}
& S_{\max }=700+300=1000 \mathrm{Mpa} \\
& S_{\min }=700-300=400 \mathrm{Mpa}
\end{aligned}
$$

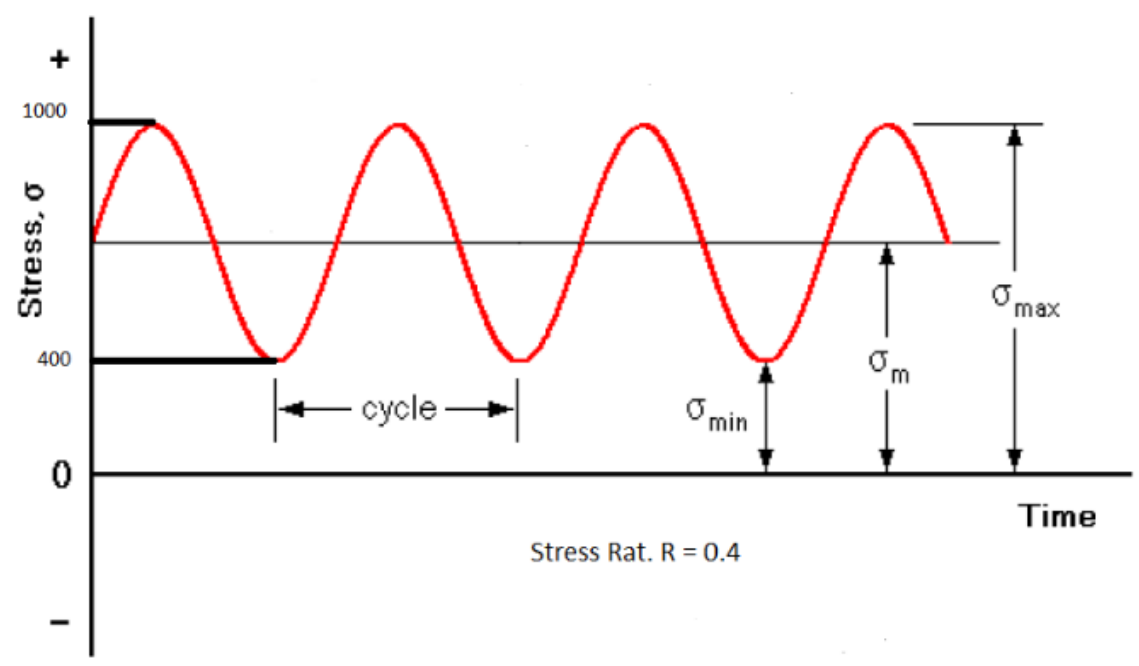

Figure 13. Original Model Cyclic Loading Parameters

Fatigue life refers to the number of cycles to fracture, and calculated as:

$$
\begin{aligned}
& b=\left(\frac{1}{3}\right) \times \log \left(0.8 S_{u t} / S_{e}\right)=-0.0247 \\
& c=\log \left[\left(0.8 S_{u t}\right)^{2} / S_{e}\right]=1.82 \\
& \mathrm{~N}=10^{-c / b} \times S_{a}{ }^{1 / b}=5.6 \times 10^{4} \text { cycles }
\end{aligned}
$$




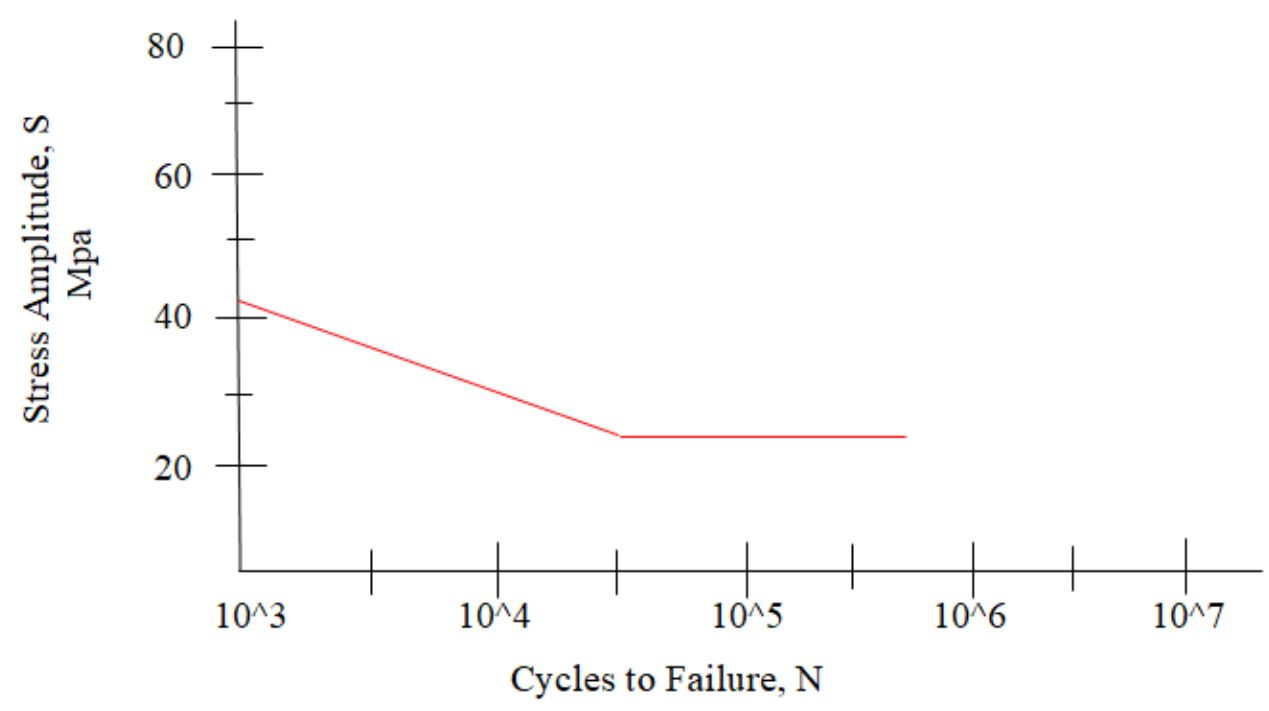

Figure 14. S-N Diagram of Original Model

If assumptions that every 5 minutes is the usage of one cycle, and one week is 40 working hour. Then the life expectancy of the acceleration pedal is 2.5 years.

\section{Improved Model S-N Diagram}

The acceleration pedal shaft has a principal stress of $120 \mathrm{Mpa}$ at maximum stress and principal stress of $24 \mathrm{Mpa}$ at the minimum stress. The amount of force exerted on the surface area of the acceleration pedal would be:

$$
\begin{aligned}
& S_{m}=120 \mathrm{Mpa} \\
& S_{a}=24 \mathrm{Mpa}
\end{aligned}
$$

Now, to determine the stress components:

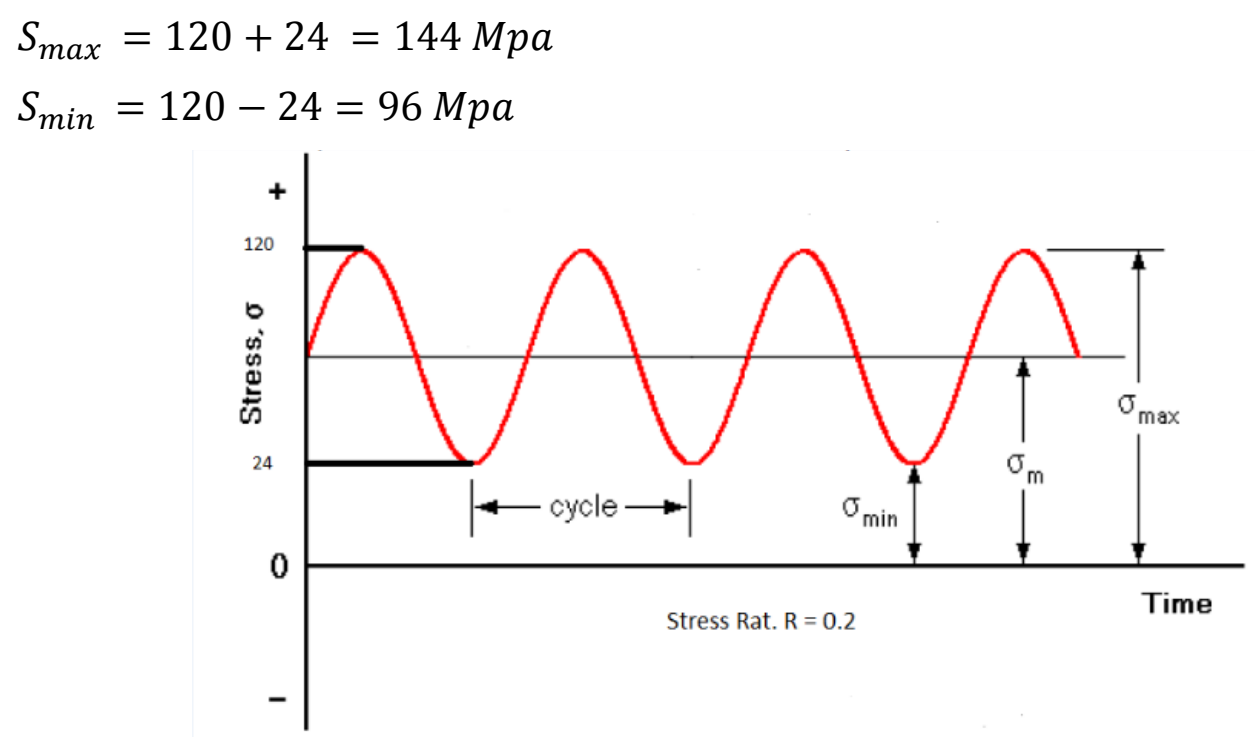

Figure 15. Improved Model Cyclic Loading Parameters 
Fatigue life refers to the number of cycles to fracture, and calculated as:

$$
\begin{aligned}
& b=\left(\frac{1}{3}\right) \times \log \left(0.8 S_{u t} / S_{e}\right)=-0.067 \\
& c=\log \left[\left(0.8 S_{u t}\right)^{2} / S_{e}\right]=2.7 \\
& \mathrm{~N}=10^{-c / b} \times S_{a}^{l / b}=1.6 \times 10^{6} \text { cycles }
\end{aligned}
$$

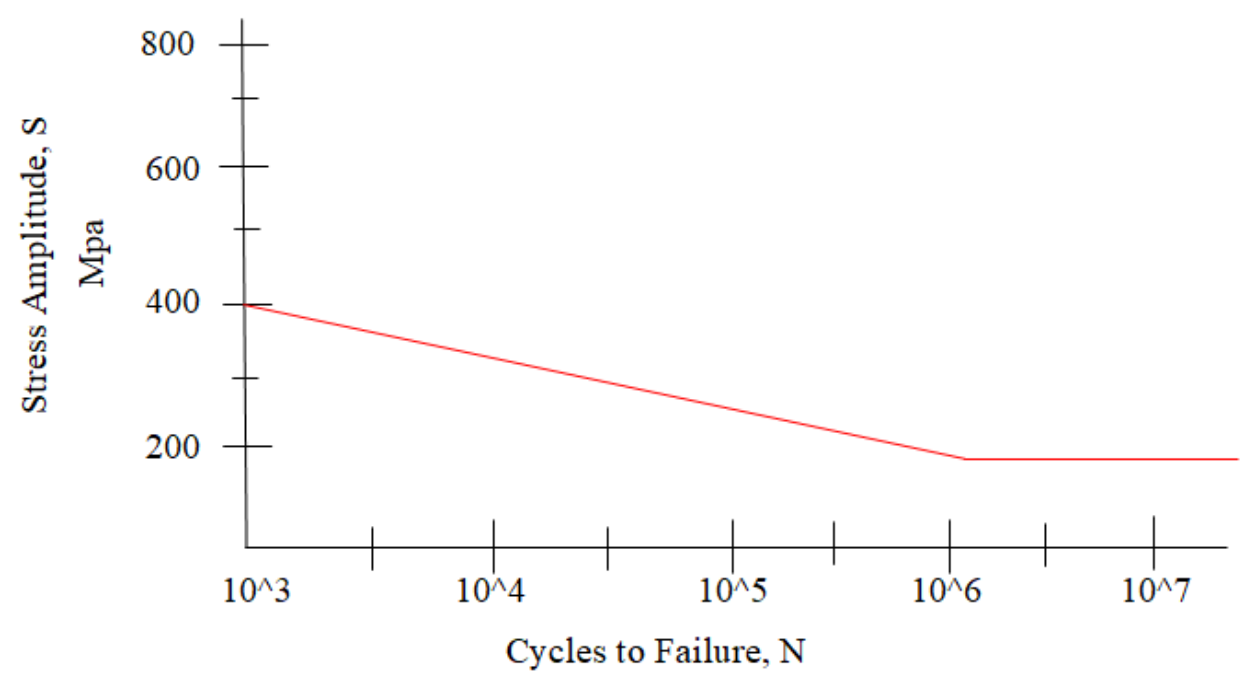

Figure 16. S-N Diagram of Improved Model

If assumptions that every 5 minutes is the usage of one cycle, and one week is 40 working hour. Then the life expectancy of the acceleration pedal is 27.4 years.

\section{Conclusions and Recommendation}

Based on manual and computation results, the amount of principal stress at the acceleration pedal failure location is surpassed the tnsile strength. With the limit of $400 \mathrm{MPa}$, while the principal stress that acted on the design is $1090 \mathrm{MPa}$.

By increasing the thickness and width of the design, the acceleration pedal has managed to reach its intended reliability and safety. Proven by the amount of load stress that acted on the acceleration pedal that still below the Tensile Strength. With only around $220 \mathrm{MPa}$ at the failure location.

Based on fatigue life calculation, the original model life expectancy is $5.6 \times 10^{4}$ cycles or 2.5 years while the improved model life is $1.6 \times 10^{6}$ cycles or 27.4 years.

It is recommended that the design of acceleration pedal to be revised and improved as it promotes the effectiveness and safety of the material. Adding some design strategy is important in order to avert or reduce the likely of brittle failure of the material. Also the handle for connector and other supporting components are carefully revised during design and testing while also refer to the senior engineer and supervisor to review the design drawing closely to avoid any further failure. 


\section{References}

[1] Kraige, Meriam. Engineering Mechanics: Statics, $7^{\text {th }}$ Ed., John Wiley \& Sons Inc., 2006

[2] Ashwinin Gawande and G.E. Kondhalkar. 2017. Design Analysis and Optimization of Automotive Brake Pedal. 3International Conference on Ideas, Impact and Innovation in Mechanical Engineering. Volume: 5 Issue: 6.

[3] Pankaj Chabra, Puneet Katyal and Vishal Gulati. 2011. Concurrent Design and Prototyping of Composite Accelerator Pedal. International Journal of Advancements in Technology. Vol. 2

[4] Rutheravan. 2016. Summary of Safety Criteria in Design. Automotive Engineering Research Group (AERG). DOI: 10.13140/RG.2.1.1501.5285

[5] Capecchi, D., Ruta, G., "Strength of Materials and Theory of Elasticity in 19th Century Italy", 2015

[6] Armenàkas, A. E., “Advanced Mechanics of Materials and Applied Elasticity”, 2006

[7] Shigley, J. E., Mischke, C. R., Budynas, R. G., "Mechanical Engineering Design"

[8] Callister Jr., William D., and Rethwisch, David G. Materials Science and Engineering. 9th ed., John Wiley \& Sons, 2014. 